\title{
Networks of Criminality: The State and Crime Policy in Contemporary Democracy
}

MARK UNGAR*

Article Received: August 30, 2015
Article Accepted: May 23, 2016

Doi: http://dx.doi.org/10.12804/desafios28.2.2016.08

How to cite this article: Ungar, M. (2016). Networks of criminality: The State and Crime Policy in Contemporary Democracy. Desafíos, 28(2), 297-329. doi: http://dx.doi.org/10.12804/ desafios28.2.2016.08

\begin{abstract}
Why do so many security policies fail in Latin America? This article shows that it is difficult to uproot criminality because it is an inberent part of the development of both states and democratic regimes. More specifically, it is part of the three main networks of security providers: the executive branch; the criminal justice system; and the sector of armed non-state entities. Relations within and between these three networks reflect their own interests and powers rather than public security, undermining policy from the beginning. This article will apply this analytical framework to two principal dimensions of public security in Latin America. One is of illegally trafficked goods, such as narcotics; the specific case study bere is of the trafficking of firearms. The second dimension is the set of security policies in a country, which range from iron fist crackdowns to community policing. The case study is Honduras, which has endured nearly every security problem that afflicts the region, responding with policies that failed for 15 years until they began to shift attention toward the networks of criminality that were obstructing them.
\end{abstract}

Keywords: Criminality, Violence, Police, Democracy, Latin America.

* Professor of Political Science and Criminal Justice of the City University of New York. He is the author of two books on judicial and police reform in Latin America and is works with the United Nations on security sector reform. E-mail: MUngar@brooklyn.cuny.edu 


\title{
La Red de Criminalidad: El Estado y las Políticas de Seguridad en América
}

\section{Resumen}

¿Por qué fracasan muchas politicas criminales en las democracias latinoamericanas? Este articulo muestra que es difícil de desarraigar la criminalidad porque es un elemento al centro del desarrollo del estado y el régimen democrático. Especificamente, es parte de las tres redes principales de los proveedores de seguridad: el poder ejecutivo; el sistema de justicia criminal; y la red de grupos armos no estatales. Las relaciones dentro de y entre estas redes reflejan sus intereses y poderes en vez de la seguridad pública, entorpeciendo las políticas de seguridad desde el principio. Se aplica este análisis en dos áreas principales de seguridad pública. Uno es contra un bien (como las drogas) que una fuente de actividad ilegal; su caso de estudio es el tráfico de armas de fuego. Otra dimensión es la rama de políticas de seguridad nacional, desde la mano dura hasta la policía comunitaria. El caso del estudio es Honduras, un país que ba sufrido de todos los problemas de seguridad - con políticas de seguridad que ban fracasado por 15 años, antes de que se cambiara su foco en las redes de criminalidad. Palabras clave: crimen, Violencia, Policia, Democracia, Latinoamérica.

\section{A Rede de Criminalidade: O Estado e as Políticas de Segurança na América}

\begin{abstract}
Resumo
Porquêfracassam muitas politicas criminais nas democracias latino-americanas? Este artigo mostra que é dificil de desarraigar a criminalidade porque é um elemento ao centro do desenvolvimento do estado e o regime democrático. Especificamente, éparte das três redes principais dos fornecedores de segurança: o poder executivo; o sistema de justiça criminal; e a rede de grupos armados não estatais. As relações dentro de e entre estas redes refletem os seus interesses e poderes em vez da insegurança pública, entorpecendo as políticas de segurança desde o princípio. Aplica-se esta análise em duas áreas principais de segurança pública. Um é contra um bem (como as drogas) que uma fonte de atividade ilegal; o seu caso de estudo é o tráfico de armas de fogo. Outra dimensão é a rama de políticas de segurança nacional, desde a mão dura até a polícia comunitária. O caso do estudo é a Honduras, um país que tem sofrido de
\end{abstract}


todos os problemas de segurança com politicas de segurança que tem fracassado por 15 anos, antes de que se mudara o seu foco nas redes de criminalidade.

Palavras- chave: Crime, Violência, Polícia, Democracia.

\section{Introduction: A New Theoretical Framework}

Despite steady economic and political progress, criminality is one of the few common afflictions among the world's otherwise divergent regimes. To tackle it, officials throughout the world have reformed their security sectors with more decentralization, judicial oversight, or community-oriented policing. But even the most carefully crafted change is undermined by obstacles such as public pressure for short-term results. Scholarship discusses why such impediments make crime more impervious to reform than most other issues. It has not yet, however, delved into the deeper malady from which it derives. Criminality is persistent and ingrained, this article asserts, because it is rooted in a network of security providers that is intrinsic to state and regime development. This network responds more to the exchange of goods - money, information, and power - than to the public good. The results are not just more crime, but injustice, corruption, and other ills that fuel it and make it harder for democracies to curb it. This network has both vertical depth and horizontal spread: it is woven into the historical development of institutions, and in the current era has an unprecedented global span.

Drawing on the experience of Latin America and building on two areas of scholarship -state/regime development and network analysis - this article formulates a theoretical framework to more deeply explain criminality's nature, persistence, and resistance to reform. It argues that because these networks are engrained into the essence and evolution of the state and regimes, criminality is built into most of the world's democracies, which then struggle to disentangle themselves from it. The first section of this article outlines this framework in greater detail. The main components of this network and framework, described in the second section, are the three main networks of security providers: officials who form security policy; 
the criminal justice system that handles crime; and the set of nonstate armed actors. Together, these three overlapping networks form a lattice of corruption, crime, violence, and insecurity. To apply this framework, the article will then examine how these networks erode policies designed to reduce crime. It will cover two main areas of such policies: against illegal trafficked goods, with a focus on firearms; and overall crime in a country, with a focus on the case study of Honduras. This model, in short, will be applied by showing how it weakens a policy intended to weaken crime.

\section{State and Regime Evolution}

State Formation: Criminality's contemporary manifestations, from institutional weaknesses to narcotrafficking, have been the focus of many explanatory frameworks. One set of frameworks centers on the state and its formation, highlighting the violence with which states are built. State scholars like Moore (1993), for example, cite the violence they use to balance external and internal pressures. Tilly, most relevantly, sees state-making itself as analogous to organized crime (hereafter OC), since both are led by "coercive and self-seeking entrepreneurs" who best others in extracting resources, accumulating capital, and providing "protection" (1985, p. 169). They skillfully mobilize armed groups to wage war or seize territory, and then either disband or outlaw those that became a threat or outlive their purpose. Those that remain useful are integrated into the state as police or military; to paraphrase Thomson (1994), bandits became troops and pirates became sailors. That process continues as states and regimes themselves continue to evolve. For example, in June 2016 an investigation into the ousted President of Guatemala revealed that his entire political party was a network of bribery, favoritism, and kickbacks that gained power and wealth through connections to a network of wealthy private actors (Associated Press, 2016).

Regimes: This history was led by dictatorial regimes, of course, since political repression goes well with violent criminality. Democracy should be the most effective way to finally end this pattern, considering it is the only regime type centered on rule of law measures to 
curb criminality. But the transition literature, of course, has shown that contemporary democracy has not yet realized that goal. Even though more countries have formally adopted democracy than at any other time in history, they have yet to ensure electoral freedom, media independence, and its other essential elements - many measured with "metrics" like political prisoners or stolen votes-. A democracy depends on the state to implement its rules and policies, that is, but those states have not yet shed their violent attributes. States continue to develop along with democracies, and in many cases, with their historical head start, taking the lead.

Criminality is ingrained in this intertwined process of democratization and state formation. From Southeast Asia to West Africa, nascent democracies are consumed by crime in part because they have become not the master of, but a shell for it. When that violence is driven primarily by transnational networks, the result is often a "mafia state," run by officials who "become integral players in, if not the leaders of, criminal enterprises" whose goals become "official priorities." (Naím, 2012). While the levels control vary, the number of states succumbing to this capture are numerous, and include not just obviously weak or roguish states (e.g. Afghanistan, Guinea-Bissau, Paraguay, and Suriname), but the vast range of countries struggling through democratization (e.g. Burma, El Salvador, and Albania). In Bulgaria, for example, OC has grown rich "from drugs, smuggling, and prostitution, has merged with corporations" with "privatized state-owned assets, or has transformed its accumulated wealth into political and administrative power" (Gounev \& Bezlov 2010, p. 203). Around the world, in short, the increasing range and persistence of groups committing crime - from local gangs to global cartels - do not just stall democracy. They also challenge the Weberian state's "monopoly of the legitimate use of physical force within a given territory". Democracy may be necessary for security, but it is far from sufficient.

Networks: A second analytical framework, drawn mostly from criminology, is used to study networks, ranging from urban youth to international business. Such networks are often mapped through social network analysis (SNA), centered on the nature, number, distance, 
and links among a network's elements. More exponential networks have nodes with similar number of links, for example, while scale-free networks like transportation systems center on a small number of nodes (the hubs) with many. SNA also focuses on the embeddedness of network nodes in society, as well as the muliplexity of their connections. Al Capone's mutually-supporting criminal, personal, and legitimate networks demonstrate such features (Baker \& Faulkner, 2009; Kadushin, 2012; Papachristos \& Smith, 2014). Like systems theory, SNA further shows how relations among nodes shift in response to underlying asymmetries or external pressures (Kessler, 2004; Morçol, 2012; Paoli, 2004).

SNA's applicability is often most dynamic when applied to the market sphere. No matter their stage of transition, every contemporary democracy is embedded in a global market economy that their under-developed state structures struggle to navigate and regulate. Growing crime has made security one of the fastest-growing of those markets, as seen by an astronomical growth in private security firms. Another fast-growing but less documented non-state sphere is of entities providing security illicitly, such as rural militias, vigilante squads, business guards, errant community policing groups, and others that thrive where the state is weak. Many of these groups are connected to organized crime, from gangs to narco-traffickers and other organizations that dominate security in areas under their sway. In the current era of great technological and political change, as studies show, OC shed some of the constraining traits attributed to it in much of the literature, such as being monopolistic and hierarchal (Abedinsky, 2010). Since syndicates adopt the most profitable tactics - constantly splintering and collaborating as they identify and seize new opportunities - typologies increasingly conceive of them as a range of activities or a continuum of behaviors (Maltz, 1976; Hagan, 2010) rather than as structured organizations (Smith, 1980). This emerging SNA approach has important policy applications. Since more exponential networks better absorb external pressures, for example, a lesson Mexican cartels like Sinaloa successfully drew from their more hierarchal predecessors in Colombia was to adopt more decentralized, multi-spoked networks. As studies show, the current 
era's unprecedented levels of communications, movement, and access have created perhaps history's most hospitable environment for such networks. At the local level, OC is strengthened by inroads into community politics, economies, and public legitimacy facilitated by local security providers discussed above, from state police to private militias. In rural areas, for example, illegal mining and logging operations have built roads and scouted out exploration for larger global firms. Organized crime is still organized, but in ways that attach to, rather than set it apart from, the state. Networks connect providers of security, from executive policymakers at the center of the state to transnational syndicates on its far reaches, and the informal entities in between.

A new Analytical Framewor: The article's analytical framework brings these two areas together: how the networks of security providers evolve as part of state and regime development. While those relationships are different in each national context, they share common features that provide a fuller and more accurate picture. Relationships of weak coordination, for example, harm networks of policymakers and criminal justice agencies but strengthen non-state networks.

This framework's empirical foundation is Latin America, whose homicide rate has been more than three times the global average since 2000 , with over $40 \%$ of the world's annual murders. ${ }^{1}$ The region also exemplifies the threat of organized crime, whose tenacity is all the more striking amid the region's great economic and political advances. Its specific case study is Honduras, which has experienced a confluence of every type of criminality. This article establishes a framework that is more comparative across borders and over time by incorporating the full spectrum of actors shaping the use of violence. It will add to democratization scholarship by showing how security is a large but largely overlooked part of how stalled transitions settle into semi-authoritarian hybrids, giving rise to obstacles such as reserve

\footnotetext{
1 Latin America's average annual homicide rate has been 27.5 per 100,000 people, and the world rate has been 8.8. Interpol International Crime Statistics, http://www.interpol. int
} 
domains of power (Linz \& Stepan, 1996; Schmitter \& Karl, 1991; Mainwaring \& Pérez-Liñan, 2014).

\section{Networks and Relationships}

Providers of security - defined as those with a role in the use of armed violence, from Presidents to narcotraffickers - fall into three overlapping networks: policymakers who determine criminal policies; the criminal justice system that responds to crime directly; and the non-state armed sectors, which ranges from private security firms to transnational organized crime cartels. As this section will assert the relationships within and between them - particularly of coordination - are the core source of Latin America's criminality.

a) Policymakers: The center of the state is the executive branch, which forms and implements state policy. Dominant Presidents are considered one of the biggest impediments to democracy in Latin America, mainly because of the lack of balance with the other two branches. Their administration of security agencies making that dominance particularly pronounced in security. Most countries' Congresses lack the human, political, or financial resources to question executive policy or oversee operations. In contrast to heated debates in cases such on New York's stop-and-frisk tactics, very little questioning occurs in Latin American legislatures. But largely underestimated is how relations within policymaking network, even those led by overbearing Presidents, shape and often weaken democracies' ability to fight criminality.

As the top public concern since the mid-1990s that has spurred the biggestprotests in Latin America since its transition to democracy in the 1980s, first of all, crime has become a pivotal political and electoral issue, often ramping up tough anti-crime rhetoric to the point of breaking taboos like the

\footnotetext{
2 Crime has become the most common response in the Latinobarómetro survey (of 20,212 people in 18 countries) to the question, "What do you consider to be the most important problem in your country?" In 2002, $7 \%$ said crime was the biggest problem and $25 \%$ said it was unemployment; in 2010, 27\% put crime first, with unemployment second at 18\%.
} 
death penalty. Even progressive candidates - like Costa Rican President Laura Chinchilla (Huhn, 2012) or Chilean President Michele Bachelet ${ }^{3}$ - get caught up in this pressure. But after elections, candidates quickly discover the difficulty of reforming entrenched agencies. Facing their term's ticking clock, Presidents thus often forego institutional reform in favor of giving the police more high-tech resources and legal authority. Adding to this pressure in many countries is civil strife, making security a matter of governmental survival as well as of success. The police's political sway is thus amplified by its need to contain agitation that can culminate in government-threatening protests. In all six collapses of democratic regimes in Latin America since 2000 , in fact, internal security forces played a pivotal role by participating in, aggravating, or failing to curb unrest. Other cases that were near misses, such as police mutinies in Bolivia in 2003 and in Ecuador in 2010, showed that the police are one of the few state agencies that can turn its own labor disputes into constitutional crises.

Even though Presidents dominate security policy, second, that policy is hardly consistent, linear, or clear. The difficulty of translating campaign promises into institutional reform, as discussed above, is often rooted in the fickleness of approaches and foreign donor interests. As crime resists different policies, above all, Presidents tend to rotate through security ministers and police chiefs, giving them little time or ability to initiate new policy directions. Anticipating a short spell in office, many are also reluctant to make enemies within the security system. That difficulty is compounded by changes in paradigms and foreign interests. In Latin America and other regions, external actors - ranging from government donors to international organizations - often promote new approaches whose translation into policy is often unclear or counter-productive. One example is community policing, a general term enjoying a long spell of support in the West that often leads to superficial and ephemeral programs. Such policy inconsistency is compounded by frequent changes in go-

\footnotetext{
3 When one candidate in Chile's 2005 Presidential election called for a "three strikes you're out" law, socialist candidate Bachelet responded by calling for "one strike you're out" (Dammert, 2005).
} 
vernment, party control, ministers, or external funding itself (such as the drawdown of US funding of Bolivia's anti-narcotics operations).

Because of its popularity, a common policy is formation of new forces - particularly elite intelligence squads. Such expansion has many reasons; creating vetted agencies from scratch, in particular, can minimize corruption. Once established, though, agencies easily justify their own growth: success gives them a rationale to request more resources, while failure boosts the argument that more is needed. Those kinds of demands are common in countries facing real or manufactured security threats, like Algeria, Egypt, Iran, or Russia. But in democracies, it undermines accountability and coordination, as agencies try to outdo each other with more aggressive operations and political networking. In addition to the changes in officials, as discussed above, coordination is made trickier by the range of policies involved. As a growing middle class turns Latin American countries into consumer markets as well as transshipment points, for example, drug policy must encompass consumption, distribution, addiction, and other issues with often irreconcilably contrasting approaches among state agencies, from military interdiction to social service prevention. Militarization, simultaneously appealing to iron fist demands and quelling societal unrest, is a particularly popular strain of such proliferation. Generally regarded as the use of the military in internal security, militarization actually has many less visible dimensions, such as adoption of military tactics by police; special operations and raids, such as against gangs; use of elite soldiers in border actions, as with Guatemala's Kaibiles; occupations of high-crime areas, as in Argentina's Buenos Aires province; military posts and patrols in highcrime areas, as in Venezuela's Federal District; and formation of joint military-police drug units, as in Mexico and the Andes.

As the state network grows, security agencies play on Presidential vulnerability to the politics of insecurity to gain autonomy as well as influence. A focus on regimes and networks can highlight such unseen relationships. An examination of financial relationships, for example, often do not bring in the police's non-transparent accounting, special security outlays, control over revenue streams, and involvement 
in illegal trades. Beyond usual suspects like customs offices, security units handling accounting, financial transactions, conflictual sites like mines, or the movement of goods earn money in kickbacks and contracts. Many countries' identification offices are run by the police with a hefty off-the-books profits, while agencies providing special services to current or retired officers, such as the housing office or benevolence society, acquire funds and influence through dues and connections to financial institutions. Most mechanisms to report corruption, centered on individual cases, cannot grapple with such institutionalized relationships.

All of these weaknesses are multiplied at the regional and local levels through decentralization, the biggest single modern transformation of Latin America's states. Transferring authority on issues like security to provinces and cities makes sense (Ostrom, 1975; Oxhorn et al., 2004), since they more ably respond to local concerns and acquire the citizen knowledge and trust needed to prosecute crime. Like many changes in governance, though, decentralization has lacked adequate deliberation and implementation, leading sub-national forces to amplify the poor management, accountability, and policies of their national progenitors. On security, in particular, decentralization has created highly dispersed networks detached from cohesive policy. For example, Venezuela formed 105 new agencies after the 1989 Decentralization Law (a 363 percent increase), worsening coordination that contributed to skyrocketing crime over the same period. Further limiting the abilities of municipal governments are their high levels of personnel turnover, corruption, and patronage. The median tenure of security chiefs in Mexico's municipal police is just two years (Sabet, 2012, p. 75) - much like the national rotation of ministers discussed above - which encourages high-publicity but short-lived projects like special squads that complicate coordination and divert focus from core tasks like community relations.

Decentralization also confuses information, a critical but weak pillar of criminal policy. Just as the free market is distorted by hidden and imperfect information, a lack of reliable criminal statistics makes it difficult for governments to fight crime. Estimates of the rate of un- 
reported crimes, most seriously, reaches up 70\% in many Latin American countries, and the crimes that are reported often lack reliability and consistency from their municipal and state sources. In Mexico, a centerpiece of the security structure is the Plataforma México (PM), a database that compiles and cross-references all crime statistics. But the PM is undermined by unregulated and unanalyzed information provided by state governments. One official in Quintana Roo state said that he often reports the same statistics as the previous year, for example, and officials for the Sistema Nacional de Seguridad Pública (SNSP) estimate that $30 \%$ of municipalities receiving federal security funds do not send back sufficient information. A lack of information also characterizes non-state networks, but usually propels rather than hinders them. A lack of shared information such as the names of co-conspirators, for example, gives each node another level of protection from informants. ${ }^{4}$

In addition to the lack of police units at the local level is the lack of checks on them, such as by the media and rights groups. The sway of local police is thus amplified, giving them pivotal roles in nonsecurity matters, from land tenure to small business. Such distraction makes them even more unprepared for security challenges, such as when a national battle against OC leads to displacement of criminal networks. In an illustration of SNA, for example, Central American gangs broken up by police retreat to and re-group in smaller municipalities that have a harder time handling them. In Mexico, many drug cartels fragment into small groups that - lacking centralized directives, controls, or funding - turn toward crimes like armed robbery and extortion of small businesses. In Mexico's capital, decentralization increased insecurity by creating "gaps in authority and power" that fostered abuse and corruption by new and old agencies jockeying for territorial control (Davis, 2003). Decentralization, by making it more difficult for poorer districts to pay for police, also aggravates the already uneven distribution of security forces and thus exposing large areas to high levels of violent and organized crime. As with

4 Other examples include illegal immigration from China (Zhang, 2014). 
the "brown spaces" of minimal state control in large parts of Latin America (O'Donnell, 1993), this patchy presence then opens a window for criminal networks to integrate themselves into the familial, landowning, and extractive networks dominating regions from Petén in Guatemala to Pará in Brazil. While decentralization makes OC nimbler, in short, it makes the state more fragmented.

Together, these relationships within the policymaking network - politics, rotations of officials, proliferation, and external interests - make security policy weak, ad hoc and untenable. The thickest strands in this tangle of policies, in particular, promote contradictory approaches of tough repression on one hand and preventative social approaches on the other. The impacts reverberate widely. As discussed below, for example, greater police empowerment, combined with weak institutional accountability, aggravate abuse of due process rights on the street and in the courts. As constant reshuffling of security chiefs or structural organizations undermines internal collaboration, individual agencies develop links with non-state entities. Within society, half-hearted community policing projects are easily coopted by neighborhood cliques which, in cities like Caracas and La Paz, are also vigilante squads or drug dealers. In Mexican states like Guerrero, citizen security groups established for community protection get pulled into illicit trade. More broadly, growing societal disillusionment with policing allows OC groups to offer more security and money positioning themselves as protectors of local interests and security.

b) Criminal Justice: Exchanges of power and money are expected in the arenas of policy. From individual cases to national legislation, the judicial branch of a democracy is expected to be above and thus help limit such exchanges. As in policy, though, criminality has eroded that role. In particular, all four main sets of criminal justice agencies police, prosecutors, judges, and prisons - operate in a network that allows impunity to supersede justice.

The first stage of the criminal justice process is carried out by the police, whose main role is to prevent crime and capture individuals responsible for those that do occur. Police throughout Latin America 
and other regions, though, do poorly at addressing crime through all their available means, such as community cooperation or investigation. In most countries, in particular, criminal investigation is undermined by competition among agencies, poor training, citizen distrust, and a lack of funds and equipment. Police reports often lack the evidence and witnesses needed for trial, as a result, contributing to Latin America's dismal average of under five percent of homicides leading to trial and conviction.

Prosecutors lead the second stage of the criminal justice process. Nearly every Latin American country suffers from a lack of detectives, adequate budgets, specialized prosecutors, cooperation with the police, and local offices that can acquire citizen trust and information - which, together, lead to extensive delays in most cases during which evidence fades and witnesses become scarce. In addition to regular crime, poorly-run and often corrupt National Attorney General Offices (Fiscalias) handle complex organized crimes like money laundering. But even with sweeping laws against "illicit association" and "terrorism" that expand prosecutorial power, actual prosecution is impeded by the sheer amount, variability, and reliability of information; the need to restrict access to that material; the lack of specialists and standard investigatory protocols; the length of complex investigations; and sporadic international cooperation. Criminality takes full advantage of those chronic deficiencies. In Guatemala, such paralytic conditions led to establishment of the first United Nations agency designed to root out judicial corruption. In its work, the Comision Internacional contra la Impunidad en Guatemala (CICIG), issued a 2012 report naming judges whose rulings and obstruction "created spaces of impunity" for Illegal Clandestine Security Apparatuses (CIACS), consisting of current and former members of security forces involved in drug trafficking and other illegal activity. Guatemalan officials have not followed through on most of CICIG's recommendations (CICIG, 2012), and in 2014 ousted the Attorney General, who made real headway against OC.

The third and most powerful set of judicial officials, of course, are judges. Limits on judges in democratizing world have been well es- 
tablished. Among them are politization, rooted in partisan selection that continues despite reforms such as establishment of judicial councils; and inefficiency, rooted in case overloads and slow bureaucracies. As with prosecutors, these limits are amplified in the area of citizen security. On a daily basis, judges tend to select incarceration over alternative sentences in order to appear tough on crime. More distantly but powerfully, jurisprudence and court rulings further undergird the criminal justice's inherent weakness in combatting crime within a rule of law. While their independence has clearly grown, many judges admit that crime is the area in which their range of decision-making feels narrowest. Jurisprudence is often couched in a wide interpretation of "police power," in which the realm of power extends to controversial practice such as police edicts and warrantless arrests. A wide interpretation over the proper extent of "police power" in Latin American history allows many judges to continue leaning toward this more controversial but politically safer understanding of the state's police power.

After court trials, the final stage of the criminal justice process is the penitentiary system. As has been well documented, prisons in much of the world are markets of money, power, status, and violence. Sensational escapes by drug kingpins in Mexico or the control of PCC in Brazil grab headlines, but autonomy also characterizes daily life of prisons throughout Latin America, with prisoners running activities from food and bedding to security and access. Most of the deadliest prison tragedies of the past decades, for example, result from gang violence or a lack of attention to safety conditions - both reflecting minimal state control. As in the police and courts, relationships within the network direct shape practices and democratic principles.

Together, these relationships worsen insecurity by eroding principles as well as policies that sustain democracy, from constitutional rights to less measurable goals like accountability. Low accountability is particularly acute in the realm of security because executive policymaking is more hidden from public scrutiny and because oversight agencies, more than on most other issues, are unable to alter security policy even after exposure and punishment of wrongdoing, the two dimen- 
sions of accountability used in the scholarship (Schedler, Diamond \& Plattner, 1999). Such limits also increase impunity in the criminal justice systems. One example is of the reformed penal process codes that nearly all of Latin America has undertaken to strengthen due process, replace written with oral trials, transfer investigative authority from police to prosecutors, and create sentencing courts and oversight. Because of officials' inability to implement institutional changes, as discussed above, the police lack the training, resources and pressure to replace long-held practice with these codes. In the politicized security debate - often centered on the alleged divide between tough policing on the one hand and individual rights on the other - the codes then become a target of blame by police for tying their hands and encouraging judges to release violent suspects. Ecuador's police, for example, say that the new penal code is their biggest problem because it "permits detainees of police operations to be put in liberty immediately by the judicial authorities" (Policía Nacional of Ecuador, 2006).

Such politics and the ongoing lack of justice, then fuel feed society's accurate sense that whole sectors are exempt from the law. This belief then stokes apathy, fear, vigilantism, and laws that address immediate demands rather than the criminal justice system as a whole. Two of those principal sectors are at the two ends of the criminal spectrum: suspects and detainees from society's marginalized sectors who are seen to avoid punishment for property, assault and other crimes. The other is the elite sliver of high-level narco-traffickers and their political accomplices perched above the law's reach. In between are the multiple acts that are so pervasive they have become essentially invisible, from bribable police officers to regulation-skirting businesses.

3. The Non-State Network. The state's weak provision of security has provided an invaluable opportunity for non-state armed entities, from private security firms to organized crime syndicates, to provide security in many regions. Most evidently, the expansion of free markets has combined with state weakness to trigger boom in private security, whose size has quintupled in the past decade. These firms range from neighborhood businesses and bank guards to multina- 
tionals like G4S, the world's second biggest employer. The astronomical growth of private security in Latin America - in Bolivia, for example, the number of private firms jumped from 30 in 2001 to 265 in $2012^{5}$ - has given the region over 3.8 million private officers, vastly outnumbering its 2.6 million police officers (though with much overlap). In nearly every country, growing pains make the numbers too big and uncertain to track. Control is almost uniformly weak, further hobbled in federal countries by their regulatory patchworks. According to Mexico's National Private Security Council, about 80\% of private firms fall outside local, state, and federal laws. ${ }^{6}$ Amid the proliferation and decentralization discussed above, new state agencies reap benefits when they collaborate with private firms, which, in many countries, are a primary conduit of both legal and illegal weapons. As many scholars point out (Sheptycki, 2003, p. 49), changes in the market and the collaboration between state and criminal actors creates an overbearing and often violent relationships of power, control, and money that determines the level of criminality.

Unregulated, many private firms have crossed over into an even larger security realm of informal entities populated by vigilante squads, rural militias, "social cleansing" squads, business guards, neighborhood vigilantes, paid-for-hire associates, errant community policing groups, and many other entities that are the main providers of security in marginalized urban areas and isolated rural areas. As with private firms, state security agencies around the world collaborate with these groups. Provincial governments in Nigeria hired violent gangs known as the Bokassa boys to provide security, for example, while the Egyptian Interior Ministry started outsourcing security to the Cairo street gangs known as baltagiya (Amar, 2011). In Latin America, such a relationship often begins within the rule of law before veering outside of it. Rural Brazil's citizen-led "indigenous police" are often allied with criminal groups, for example, while many statefunded social work groups in Venezuela become powerful enforcers in their neighborhoods, often killing opponents and trafficking drugs.

\footnotetext{
5 According to data from the Viceministry of Citizen security, as reported in Villa (2012)

6 Author Interview, Luis Oliver, Secretaría de Seguridad Pública, 10 June 2011
} 
Closely weaved into their communities, and connected with illegal trades, such informal groups have also helped expand organized crime, another set of actors of the non-state network. Along with such support, OC has also grown through collaboration among its own groups on an expanding range of goods. Along with narcotics, being trafficked around the world in greater quantities are cars, petroleum, persons, tropical animals, and psycho-stimulants like amphetamine. Those trades are facilitated by greater sharing of physical, financial, operational, electronic, and human resources. Illegal loggers in Central America have infiltrated community logging associations so well that they are often selected as association directors. On one level, campesinos are paid well to plant, hide, and transport marijuana. On another level, illegal appropriation of software and the use of malware (Honduras is the biggest national source of malicious sites, with about $7.5 \%$ of the global total) has greatly facilitated money laundering. SNA helps explain this growth. Because of rapidly changing markets in which risk is a primary determinant of prices, for example, narco-networks tend to be less dense than legitimate trades, since dispersion spreads risk (Boivin, 2014). Such dispersion also gives OC flexibility to be less or more visible, as public relations and profit dictate, and to minimize costs, paid heavily by police, as targets of criminal violence as well as of public scorn; it also facilities collusion within the non-state network.

Emergent OC groups use channels set up by semi-legal networks of prostitution, gambling, contraband, and real estate. Drug traffickers use Saharan routes paved by cigarette smugglers that crisscross West Africa, for example, while Brazil's Federal Police says that among its biggest challenges is the increasingly tight network of those trafficking items, from cocaine to hardwoods, along the borders of states with lax enforcement. ${ }^{7}$ Thanks to such collaboration, in fact, just half of drug cartels' income now comes from drugs. OC traffickers also collude with private firms, such as providing security in exportoriented agricultural zones like the coastal wetlands of Ecuador and

Author Interview, Superintendente Sergio Fontes, Chief in Amazonas State, Federal Police of Brazil, Manaus, Brazil, December 6, 2011 
Central America. In Mexico's Michoacán, powerful gangs, armed vigilante groups, and narcotics traffickers like The Knights Templar all compete and cooperate over timber, avocadoes, limes, drugs, and a long stretch of Pacific Coast. In these OC networks, some of the most important nodes are gangs dominating urban neighborhood bases and roads, as in Río, Medellin's Comuna 13 zones, and routes between the US and Mexican cities of Nogales.

Table 1 below outlines the major actors in each of the networks of security. But most of them, from political parties to community policing, extend into more than one network - strengthening the links among them.

Table 1. The Three Networks of Security Providers

\begin{tabular}{|l|l|l|}
\hline \multicolumn{1}{|c|}{ Policymaking Network } & \multicolumn{1}{|c|}{ Criminal Justice Network } & \multicolumn{1}{c|}{ Non-State Network } \\
\hline Presidents & Prosecutors (Fiscales) & Private security firms \\
\hline Legislatives & Judges & Vigilante squads \\
\hline Foreign Donors & Penitentiary & Rural militias \\
\hline Political Parties & Community Policing & Social Cleansing Squads \\
\hline
\end{tabular}

Source: The author.

Links between all three networks, which is more damaging to the fight against criminality, are also strong. As visualized in Graph 1 below, among such links are institutional overlap, policy collaboration, and corruption. Institutionally, many entities straddle all three networks. Many community policing groups in Latin America receive state funding but engage in vigilantism, for example. More formally, non-state actors collaborate on policy formation. Private firms, perhaps most problematically, have been involved in the drafting of legislation in countries such as Nicaragua or Argentina, where a 2006 law in Buenos Aires province gave private security exclusive control over guard bars and nightclubs. More informally but extensively, of course, is corruption. Beyond the bribery and extortion, are the unwritten influence on security policy among powerful families, businesses, and political parties. 
A source of the strength of these bonds is historic as well as logistic. In countries like Colombia, Mexico, and Peru, the rise of the military's power and tactics had a direct impact on the size and strength of guerrilla and narco-traffickers. Even though the state is currently moving in the opposite direction of decentralization, OC similarly thrives off of the state. In Bolivia, for example, tensions among the departments (provinces) have opened up spaces for greater OC. Mexico's Zetas, a notoriously violent murder-for-hire organization, whose leaders defected from the elite US-trained Airmobile Special Forces Groups, illegally tap over 80,000 gallons of oil a week from pipelines, tripling extraction since 2006 (Miller, 2010). A 2011 investigation found car manufacturers Ford, GM and BMW were using pig iron made with charcoal obtained through illegal logging in Para. Demonstrating how the patterns of state formation continue into eras of democratization, many such connections are made during political transitions. After WWII, for example, the Japanese police forged links with the Boryojudan, the OC syndicate known as the Yakuza, to obtain information and proceeds from the black market. Also, as the Soviet Union collapsed, the state-centered "mafia" become "endemic to the very institutions" of post-Soviet republics (Waller, 2004, p. 364). The drugs, humans, guns, wildlife, gems, timber and other contraband moved by Burma's OC, protected by officials of the forma military junta and current transitional regime alike, has an annual worth of up to US $\$ 2$ billion per year (Boot, 2012).

In sum, these bonds help explain why most security policy is both ineffective and counterproductive. Laws targeting money laundering, for instance, will often just re-channel illicit earnings into realms like tourism, and spread corruption more widely. Focusing on a specific good and on a specific country case study, the section below uses this article's analytical framework to describe such limits to security policy.

As Graph 1 illustrates, the three networks are linked through ongoing practices, from policymaking to corruption. 


\section{Graph 1. Networks of Criminality}

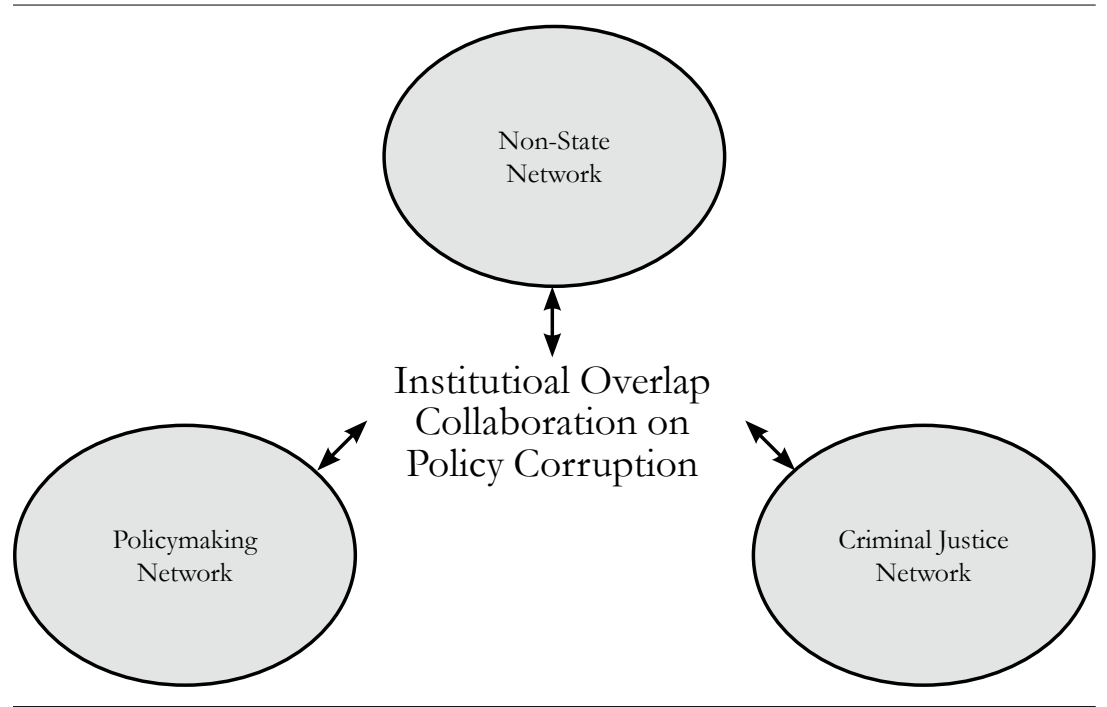

Source: The author.

\section{Case Studies}

The article's analytical framework can be used to study how networks undermine security policy. On one level, many such policies target illicit trafficking of goods. Those goods include narcotics (e.g. marijuana, heroin, cocaine, methamphetamine, pharmaceuticals); money (e.g. currency houses, gambling, money laundering); people (e.g. prostitution, human trafficking); and property (e.g. tourism centers, ranching, forestry, urban real estate). Another growing category is of natural resources (e.g. logging, rare animals, endangered animals, and flora). Patterns such as bribery for licenses and logging in Latin America's rainforests have been well documented, for example, but not how environmental policy is undermined by networks of state and non-state security agencies that collaborate with deforesters and animal traders, open protected areas to politically-powerful miners and narco-traffickers, and suppress evidence and witnesses needed to prosecute environmental crime. In Guatemala, the labor union of agriculture ministry employees conducts operations that remove and export valuable woods from the tropical Petén department. 
Another trafficked good is firearms, whose regional market opens up innumerable opportunities for collaboration among state and non-state entities. Many weapons seized during Mexico's drug war came from stockpiles in Central America, for example, including light anti-tank weapons (LAWs) and grenades supplied to Honduras by the US military. In El Salvador, the army, the police, and private security firms are all involved in the sales of weapons to criminal groups. A 2015 report described the arms trafficking operations led by an imprisoned leader of the main mara, Mara Salvatrucha (MS13). Fiscals investigating such sales are often obstructed by the military, including withholding of evidence in official investigations. The state's vacillation between accommodation with and crackdowns on the gangs also makes policy ineffective, aggravated by a lack of cooperation between the national and municipal governments, such as on the program Muncipalidad Libre de Armas. Guatemala displays similar relationships among security networks that also severely limit arms policy. In 2010 alone, 27,000 arms from Guatemalan military went to criminal groups in Guatemala and Mexico. Guatemala's national arms control agency, DIGECAM (Dirección General de Control de Armas $y$ Municiones) has lists of families with hundreds of weapons, many in OC-dominated border areas. But because of a constitutional right to possess firearms, and a lack of coordination among agencies, there is no legal investigation of them. Even though it is part of the Defense Ministry, DIGECAM does not monitor military stocks, from which many weapons are sold illegally. There are also about 40 private businesses that import weapons, often in trucks that bring cocaine to the US. Criminal justice agencies struggle to keep up with arms tracking and testing. INACIF (Instituto Nacional de Ciencias Forenses), has the personnel to test just 100 arms monthly, creating a backlog of about 4,000 cases. The country's primary commission on arms control, the Comision Nacional Mulidisciplinaria en materia de armas y municiones (MDN), grapples with a lack of coordination and mistrust among all of these agencies. Even though the MDN has representatives from the military, the executive and the other branches, as a result, it struggles even with its main goal of enacting new arms legislation. Commissions are not even sure of any kind of legislation would be approved by the country's' fractious Congress. 
The range of security policies in a country can also be understood through this framework. Honduras is a stark illustration. The Central American country has had the world's highest murder rate since 2012 (topping 85 per 100,000 people in 2013), (Secretaría de Seguridad, Honduras) is the hemisphere's primary narcotics transit hub (over $40 \%$ of US-bound cocaine goes through its territory); and has the highest number of gang members, mareros (up to 100,000, which is more than Guatemala and El Salvador combined). This criminality has been fueled by fast-growing networks of illicit operators in areas of logging, mining, malware (Honduras is the word's single biggest national source of it), and trafficking (in persons, drugs, and other goods). State agencies, real estate firms, private security business, gangs, family conglomerates are all involved in network. Police are paid to stop protests against questionable mining concessions, many awarded illegally by a former Environmental Minister (and later disgraced adjunct Attorney General). As they develop as part of the state structure since it was overhauled in the late 1990s, relationships within the networks of policymakers, criminal justice, and $\mathrm{OC}$ - and between them - obstruct the country's security policies. Since 2003, that policy has been based on iron fist (mano dura) policing, rooted in with increasing authority on the street and draconian laws against gangs. As increasing violence and abuse open that approach to doubt, alterative policies also gained traction - two primary ones were a police purge and community-based policing. None of these policy approaches - iron fist policing and community policing - led to lasting improvements. Only when they were boosted with political support and adjusted to directly address underlying networks did they begin to curb criminality. After a description of the country's three networks, these four policies will be analyzed through the framework developed here.

First is in the executive and police. Honduras continues to expose itself to the risks of proliferation, as discussed above, by continually forming new agencies without evaluating why current ones do not function. Nine separate units work on drug trafficking and gangs, with 
widely varying assessments of their shared targets. ${ }^{8}$ Although every security minister complains of a lack of control over the police's different divisions, three new specialized agencies were formed in 2013 alone. In 2015, the government proposed yet another new Police Law, this time involving the creation of over a dozen new agencies. Much of this expansion centers on the military, which was first brought back into domestic policing scarcely five years after it was constitutionally removed from it. Every President since 2002 has flooded the streets with soldiers, launched military-police crackdowns, and created militarized domestic forces. One is a Military Police, the cornerstone of Juan Orlando Hernandez's winning Presidential campaign, whose troops were sent into the streets without the training required in its founding legislation. Two other agencies were created to fight extortion, but without incorporating the fact that the police themselves run about $40 \%$ of extortion rackets, and head squads that target political and economic adversaries, from journalists to suspected gang members (Arce, 2013). Such agencies also have a tendency to expand beyond their mandates. The country's SWAT-styled Cobras quickly enlarged from riot control to prison violence, gangs, and land occupations.

Criminal justice agencies, from the Attorney General down to detectives, are hindered by this network. The Honduran Fiscalia (Attorney General) was notoriously corrupt and ineffective, sitting on hundreds of cases over the past decade, with some prosecutors resolving no more than a handful of cases during their careers. None of its ten specialized units - such as on youth, corruption, narcotrafficking has a sufficient budget, sometimes to the point of being unable to get to a crime scene. ${ }^{9}$ Also in short supply are police detectives to work with them. Because of poor investigation, up to 70 percent of police reports are rejected by prosecutors and judges. Of the 391 homicides in the municipality of Comayagua between 2010 y 2012, in just 34 did the investigative police complete their report, and only 11 cases

\footnotetext{
8 Author Interviews, Óscar Álvarez, Minister of Security, 10 February 2003 and 9 April 2010

9 Author Interview, Vilma Cecilia Morales, Supreme Court judge and President, National Banking and Insurance Commission, Tegucigalpa, 20 May 2013.
} 
- three percent of the total - led to a trial and conviction. Over $80 \%$ of cases not investigated at all, ${ }^{10}$ and, because of their complexity, "the most serious crimes are the least investigated." 11 Prosecutors investigating organized crime have been assassinated. Investigation is undermined by incomplete training, a dearth of equipment, competitive distrust between investigative and preventative officers, and willful neglect of due process.

The third security network, of non-state entities, is of course powered in part by such weaknesses in and complicity by, state networks. Officials uncertain of their agencies' future have strong incentives to develop links with non-state entities, from private firms to OC, and to access the lucrative stream of trafficked goods. Ranging from people to electronics, those markets straddle the licit and illicit economies, making them more entrenched. One of the biggest of those goods is firearms, facilitated by police and private security agencies and barely controlled by the country's three arms control laws. This trade has brought between 600,000 and a million firearms into Honduras, which are responsible for over $80 \%$ of homicides. Officials mention nearly every major area of economic activity, in fact, as being "infiltrated" or "controlled" by OC. The state suffers from similar infiltration; the director of the National Anti-Narcotics Council says that "all state organizations working on drugs are infiltrated by drug traffickers." "12 Three nodes - private families, drug cartels, and the maras - comprise much of this non-state network. First, Mexican and Colombian drug cartels have moved heavily into Central America, particularly in Honduras's six northern departments and border areas. Mexico's Milenio Cartel even founded a business called Empresas Gastronomicas de Honduras. Cartels also recruit mareros to attend the police academy, sell drugs, guard shipments, and

\footnotetext{
10 Author Interview, Yoleth Calderón, Delegada Adjunta Primera, Comisionado Nacional of Derechos Humanos, Tegucigalpa, 6 April 2010

11 Author Interview, Danelia Ferrera, Director General, Ministerio Público, Tegucigalpa, 7 April 2010

12 Author Interview, Mirna Andino, Executive Secretary, Consejo Nacional Contra el Narcotráfico, 8 April 2010.
} 
launder profits. A criminal group in Atlántida department known as Los Grillos, for instance, helps launder money and bribe officials, for themselves and for the cartels (Wolf, 2012). A second set of nodes are families whose power ranges from top political positions to major industries. The large landowning Facussé family, for example, is a dominant influence in the media and politics; its private militias have been accused of killing protesters in land disputes (La Prensa), and some of its businesses probably traffic cocaine (Ramsey, 2012). Other narco-trafficking family conglomerates include the Maradiagas, known as Los Cachiros, whose billion-dollar business empire extended from palm oil and ranching to eco-tourism and mining. A third set of actors in the non-state network is private security. At least 400 firms are not registered with the Security Secretariat, as required by law; there is thus little knowledge of their how their 70,000 employees are trained, who the owners are, or the kinds and sources of their weapons. ${ }^{13}$ What is known, though, is that they are a major conduit for organized criminal activity, such as arms trafficking and money laundering. A third set of non-state armed actors is of the two large maras, MS-13 and $18^{\text {th }}$ Street, which have spread violence through their high levels of cohesion and ruthlessness. Collaboration among these nodes is increasing, strengthening the network; for instance, the flow of drug money into Honduras is laundered into rainforest land purchases for cattle ranching (McSweeney et al, 2014).

Because of the attributes of all three networks, policies to combat insecurity have had limited results. Its main policy, as mentioned above, is the iron fist policing that the country launched in in 2003, leading a regional trend. In addition to more autonomous police on the street, this policy was fueled by laws such as an amendment of Penal Code Article 332, commonly known as the Anti-Maras Law; Presidential decree 123-2002, which allows searches without a judicial warrant; and the 2002 Law of Police and Social Co-Existence (LPCS: Ley of Policia and Convivencia Social). ${ }^{14}$ Most arrests under these laws

\footnotetext{
13 Estimated by Association of Firms of Security and Private Investigation of Honduras, Radio HM, 2014

14 This law is criticized by constitutionalists for authorizing the police to "control" the
} 
were of low-level members, though, or with such a lack of evidence that judges released them. Maras themselves responded by shunning tattoos and other circumstantial evidence, re-grouping in smaller more rural structures that have become harder to detect, more flexible, and, in recent years, available for collaboration with transnational drug trafficking - a response predicted by SNA but unanticipated by officials. That trend then began to generate laws more focused on criminal networks, modeled on the US federal Racketeer Influenced and Corrupt Organizations Act (RICO) used effectively against the mafia, with legal powers such as property seizure, telephone registry, and conspiracy charges; but, as with private firms, such laws were not particularly effective against a non-state network that has already solidified its links with the state networks.

Given how deeply these networks are entrenched, how can they be fought? Following the logic of the analytical framework, the relationships within and between them must be targeted. For the past four years, policy has shifted in that direction, bringing long-elusive reductions in criminality. Within the criminal justice network, for example, it took years of concerted political efforts - from televised Congressional hearings in 2012 that exposed the office's inefficiency, to international funding for its specialized units - to overhaul the Fiscalía.

Similar approaches have been taken on the two main policies, mano dura and community policing. On community policing, the country constructed a new police academy, funded by the Inter-American Development Bank, and based entirely on a community-centered curriculum. By 2022, 22,500 of 26,000 police officers will have been trained under this new approach. ${ }^{15}$ To help them implement it, and

people in any given area and to arbitrarily detain "vagabonds" - people suspected of not having "licit" purposes in the neighborhood in which they are found. Much of the law's language - such as "in suspicious form" and a "state of societal danger" - gives the police wide discretion.

15 Minister of Security Julian Pacheco, Woodrow Wilson International Center for Scholars, June 16, 2016 
avoid current practices of corruption and complicity, a consensus developed in the policymaking network to strengthen accountability and administration. The difficulty of not doing has been ingrained into Honduran democracy. The Internal Affairs Office (UAI: Unidad de Asuntos Internos), set up when the country adopted a civilian police, was essentially dismantled in 2002 after its director accused police officers of extrajudicial killings. The subsequent Special Unit to Investigate Youth Deaths (Unidad Especial de Investigaciones de Muertes de Menores) documented 967 violent deaths between 1998 and 2004, 24\% of which were connected to security officers, but only three of those cases led to a conviction. Increasing abuse and corruption then led to the 2012 creation of the Office of Investigation and Police Career Evaluation (DIECP: Dirección de Investigación y Evaluación de la Carrera Policial) to administer drug, financial, and psychological tests to officers. But in two years, only 442 officers underwent tests; of them, 290 failed but just 28 of them - no top official among them - were dismissed. In an example of information's importance, in addition, a 2013 census found that nearly 5,000 of the official count of 13,000 officers did not exist and were "ghost" posts created to collect salaries. Such revelations prompted policymakers to finally give accountability political support; in December 2015, the President himself announced that he would oversee a police purge. At least publicly, the top police chiefs support these changes. ${ }^{16}$ One part of that purge was of notoriously corrupt units. Investigation of the transit police led to $70 \%$ of its officers to leave, for example, and the border police was re-structured. A far broader purge begun with formation of the Comisión Especialpara la Depuración y Transformación de la Policia Nacional in April 2016. Comprised of the Security Minister and representatives of the NGO and religious networks, in just its first four months the commission evaluated the 272 highest ranked officials, removing 106 of them. Helping limit opposition to this effort was an increase in the Security Ministry budget (which rose 45\% in 2015).

\footnotetext{
16 Interviews with José Oliva Acosta, Commissioner General; Javier Leopoldo Flores, Director of Human Resources, National Police; Hector Ivan Mejia Velasquez, Director of Operations; and Felix Alejandro Maldonado, Assistant Minister of Security. December 16, 2015.
} 
On the other main policy front, non-state networks are finally being confronted with a shift away from the mano dura, which only led to detention of less low-level criminals, and toward intelligence. A focus on local drug trafficking (narcomenudeo) for example, had strong results because it is a major source of homicide. For the more powerful nodes of non-state network, it took stronger outside support as well. In 2013, Los Cachiros was targeted with the Foreign Narcotics Kingpin Designation Act of the US Treasury, leading to confiscation of much of their property (though no immediate arrests or even charges against family members by the Honduran government). Under greater pressure as discussed below, President Hernandez is moving toward reform centered in different ways on all three security networks. Julian Pacheco, Minister of Security, is committed to a strengthening of intelligence, taking advantage of his centralized power - funded in part by a security tax that NGOs rightly say is "totally at the margins of the law." Two of the agencies leading those changes are the Dirección Policial de Investigación (DPI) and the Agencia Técnica de Investigacion Criminal (ATIC). They are developing new systems of arms registration and criminal statistics through programs like the Navy Automated Civilian Management Information System (NACMIS), which will help centralize information on criminal networks, such as specific names that will be used for formal orders of capture. ${ }^{17} \mathrm{Ad}-$ dressing long-standing coordination problems, they are also focusing on coordination with other judicial agencies, which includes a clear separation to ensure they are not working on the same cases. DPI has new mobile crime labs that bring the police to crime scenes and allow them to safeguard more evidence; a selection of 1,000 investigative agents, within six regional offices. IBIS and AFIS (Automated Fingerprint ID System) are being more widely used. The police also are developing a new manual of promotion with stronger requirements. Crime has declined from a rate of 86.47 in 2011 to 60 in 2015. ${ }^{18}$

These institutional improvements are fueled in part by a shift in relationships within the executive network. First, the United States has

\footnotetext{
17 Interview with Ricardo Castro, ATIC's director, December 16, 2015.

18 Department of Statistics, Police Statistics System, Honduras
} 
been providing more support to break up OC networks and drug trafficking, even arresting members of prominent families. A second shift is electoral; because citizen security was the foundation of his first Presidential campaign, and will be for his planned re-election, the President needs to show results that go beyond increased arrests. Finally, under pressure for a social security corruption scandal that led to widespread protest, and presumably spooked by the scandal in neighboring Guatemala that led to the President's arrest, led him to allow the creation of The Mission to Support the Fight against Corruption and Impunity in Honduras (MACCIH). Though less powerful than the CICIG in Guatemala, after which it was modeled, it will also help uncover patterns of corruption, such as the assignation of the country's drug chief by a network of drug traffickers and other police.

The power of the non-state sector can be loosened, that is, through a convergence of political pressures, incentives, and alignments - a rare combination of relationships that together demonstrate the strength of the network itself.

\section{Conclusion}

The analytical framework developed here asserts that networks of security actors - policymakers, criminal justice, and non-state groups - evolve as part of the state and regime. The relationships within and between those networks are steeped in criminality, making it difficult for a democracy to fight it.

Breaking through traditional approaches and showing why criminality persists through time and across borders, this framework can thus be used to understand criminality and criminal policy in other democracies. In Guatemala, for example, the party of the recently ousted president was itself revealed to be little more than an organized network of bribery and kickbacks. In Argentina's Buenos Aires province, the tight bond between the executive and non-state networks destroyed one of Latin America's most promising police reforms. But when executive networks cohere around policies persistently confront and 
target the relationship between these networks, as done at the city level in Colombia (Moncada, 2016) and in many high-crime areas of Mexico and Brasil, lasting progress can be made.

\section{References}

Abedinsky, H. (2010). Organized Crime. Belmont, CA: Wadsworth. Amar, P. (February, 2011). Mubarak's Phantom Presidency, Al-Jazeera English. Arce, A. (May, 2013). Honduran police accused as death squads. Associated Press.

Associated Press. (June, 2016). 23 Arrested in Guatemala Campaign Finance Case. Associated Press.

Baker, W., \& Faulkner, R. (2009). Social capital, double embeddedness, and mechanism of stability and change. American Behavioral Scientist 52(11), 1531-1555.

Boivin, R. (2014). Drug Trafficking Networks in the World Economy. In Morselli, C. (Ed.). Crime and Networks. New York: Routledge.

Boot, W. (October, 2012). Burma's Fastest Growing Business: Drugs. New York Times.

Comisión Internacional Contra la Impunidad en Guatemala (CICIG). (2012). The Judges of Impunity. Guatemala: CICIG.

Dammert, L. (October, 2005). "Mano inteligente contra la delincuencia". ElMercurio.

Davis, D. (2003). Law Enforcement in Mexico City: Not yet Under Control. NACLA Report on the Americas, 37(2), 17-24.

Gounev, P. \& Bezlov, T. (2010). Examining the Links between Organised Crime and Corruption. Sofia, Bulgaria: Center for the Study of Democracy.

Hagan, F. (2010). Crime Types and Criminals. Thousand Oaks, CA: Sage.

Huhn, S. (2012). Criminalidady Discurso en Costa Rica: Reflexiones Críticas sobre un Problema Social. San José: Flacso.

Kadushin, C. (2012). Understanding Social Networks: Theories, Concepts, and Findings. New York: Oxford University Press.

Kessler, G. (2004). Sociología del Delito Amateur. Buenos Aires: Paidos.

La Prensa. (November, 2010). Honduras: Facussé acusa a Ham por los asesinatos. La Prensa. 
Linz, J. \& Stepan, A. (1996). Problems of Democratic Transition and Consolidation: Southern Europe, South America, and Post-Communist Europe. Baltimore: Johns Hopkins University Press.

Mainwaring, S. \& Pérez-Liñan, A. (2014). Democracies and Dictatorships in Latin America. Cambridge: Cambridge University Press.

Maltz, M. (1976). On Defining 'Organized Crime': The Development of a Definition and a Typology. Crime and Delinquency 22, 338-346.

McSweeney, K., Nielsen, E., Taylor, M., Wrathall, D., Pearson, Z., Wang, O. \& Plumb, S. (2014). Drug Policy as Conservation Policy: NarcoDeforestation. Science 31, 343(6170): 489-490.

Miller, T. (January, 2010). Mexico: Corporate Hit Men Find New Ways to Turn Profit. NACLA Reports on the Americas.

Moncada, E. (2016). Cities, Business and the Politics of Urban Violence in Latin America. Stanford: Stanford University Press.

Morçol, G. (2012). A Complexity Theory for Public Policy. New York: Routledge. Moore, B. (1993). Social Origins of Dictatorship and Democracy. Boston: Beacon Press.

Naím, M. (2012). Mafia States: Organized Crime Takes Office. Foreign Affairs $91(3), 38$ - 42

O’Donnell, G. (1993). "On the State, Democratization, and some Conceptual Problems” Notre Dame: The Helen Kellogg Institute for International Studies, Working Paper 192.

Ostrom, E. (1975). On Righteousness, Evidence, and Reform: The Police Story. Urban Affairs Review 10(4), 464-486.

Oxhorn, P., Tulchin, J. \& Selee, A. (2004). Decentralization, Democratic Governance, and Civil Society in Comparative Perspective: Africa, Asia, and Latin America. Washington, DC: Woodrow Wilson Center Press.

Paoli, L. (2004). The Illegal drugs market. Journal of Modern Italian Studies 9(2), 186.

Papachristos, A. \& Smith, C. (2014). The Embedded and Multiplex Nature of Al Capone. In Morselli, C. (Ed.). Crime and Networks. New York: Routledge.

Policía Nacional de Ecuador. (2006). Saludo a cargo del señor comandante general. Quito: Policía Nacional de Ecuador.

Radio HM.hn. (2014). “Más de 400 empresas de seguridad privada operan ilegalmente en Honduras". Retrieved from http:/ / www.sgumava.info. seguridad_riva_en_america_lainta.html 
Ramsey, G. (2012). "Honduras Tycoon Accused of Drug Ties Names" Press Predator, InSight Crime, Retrieved from www.insightcrime.org Sabet, D. (2012). Police Reform in Mexico. Stanford: Stanford University Press. Schedler, A., Diamond, L., \& Plattner, M. (Eds.). (1999). The Self-Restraining State. Boulder. CO: Lynne Rienner Publishers.

Schmitter, P. \& Karl, T. (1991). What Democracy Is ... And Is Not. Journal of Democracy, 2(3), 75- 88.

Sheptycki, J. (2003). Global law enforcement as a protection racket. In Edwards, A., \& Gill, P. (Eds.). Transnational Organised Crime. London: Routledge.

Smith, D. C. (1980). Paragons, pariahs, and pirates: A spectrum-based theory of Enterprise. Crime and Delinquency. 26(3), 358-386.

Tilly, C. (1985). State Formation as Organized Crime. In P. Evans, D. Rueschemeyer, \& T. Skocpol. (Eds.). Bringing the State Back In. Cambridge: Cambridge University Press.

Thomson, J. E. (1994). Mercenaries, Pirates, and Sovereigns. Princeton, NJ: Princeton University Press.

Waller, J. M. (2004). Organized Crime and the Russian State. Demokratizatsiya 2(3), 364-83.

Wolf, S.(2012). El Nexo entre las Maras y el crimen Organizado. In H. Mathieu \& C. Niño Guarnizo (Eds.). Anuario 2012: de la Seguridad Regional en América Latina y el Caribe. Bogotá: Friedrich Ebert Stifting. Zhang, S. (2014). Snakeheads and the Cartwheel Network. In C. Morselli (Ed.). Crime and Networks. New York: Routledge. 
